\title{
The inverse hazard law: Blood pressure, sexual harassment, racial discrimination, workplace abuse and occupational exposures in US low-income black, white and Latino workers ${ }^{\text {is }}$
}

\author{
Nancy Krieger ${ }^{\mathrm{a}, *}$, Jarvis T. Chen ${ }^{\mathrm{a}}$, Pamela D. Waterman ${ }^{\mathrm{a}}$, Cathy Hartman ${ }^{\mathrm{b}, 1}$, \\ Anne M. Stoddard ${ }^{\mathrm{c}}$, Margaret M. Quinn ${ }^{\mathrm{d}}$, Glorian Sorensen ${ }^{\mathrm{e}, \mathrm{f}}$, Elizabeth M. Barbeau ${ }^{\mathrm{b}, 2}$ \\ ${ }^{a}$ Department of Society, Human Development and Health, Harvard School of Public Health, Kresge 717, 677 Huntington Avenue, Boston, MA 02115, USA \\ ${ }^{\mathrm{b}}$ Health Dialog, 60 State Street, Suite 110, Boston, MA 02109, USA \\ ${ }^{\mathrm{c}}$ New England Research Institutes, 9 Galen Street, Watertown, MA 02472, USA \\ ${ }^{\mathrm{d}}$ Department of Work Environment, University of Massachusetts Lowell, Lowell, MA, USA \\ ${ }^{\mathrm{e}}$ Harvard School of Public Health, Boston, MA, USA \\ ${ }^{\mathrm{f}}$ Center for Community-Based Research, Dana-Farber Cancer Institute, 44 Binney Street, Boston, MA 02115, USA
}

\section{A R T I C L E I N F O}

\section{Article history:}

Available online 23 October 2008

\section{Keywords:}

Blood pressure

Health inequities

Occupational health

Racial discrimination

Sexual harassment

Workplace abuse

USA

\begin{abstract}
A B S T R A C $T$
Research on societal determinants of health suggests the existence of an "inverse hazard law," which we define as: "The accumulation of health hazards tends to vary inversely with the power and resources of the populations affected." Yet, little empirical research has systematically investigated this topic, including in relation to workplace exposures. We accordingly designed the United for Health study (Greater Boston Area, Massachusetts, 2003-2004) to investigate the joint distribution and health implications of workplace occupational hazards (dust, fumes, chemical, noise, ergonomic strain) and social hazards (racial discrimination, sexual harassment, workplace abuse). Focusing on blood pressure as our health outcome, we found that among the 1202 low-income multi-racial/ethnic working class participants in our cohort - of whom $40 \%$ lived below the US poverty line $79 \%$ reported exposure to at least one social hazard and $82 \%$ to at least one high-exposure occupational hazard. Only sexual harassment, the least common social hazard, was associated with elevated systolic blood pressure (SBP) among the women workers. By contrast, no statistically significant associations were detectable between the other additional highly prevalent social and occupational hazards and SBP; we did, however, find suggestive evidence of an association between SBP and response to unfair treatment, implying that in a context of high exposure, differential susceptibility to the exposure matters. These results interestingly contrast to our prior findings for this same cohort, in which we found associations between self-reported experiences of racial discrimination and two other health outcomes: psychological distress and cigarette smoking. Likely explanations for these contrasting findings include: (a) the differential etiologic periods and pathways involving somatic health, mental health, and health behaviors, and (b) the high prevalence
\end{abstract}

\footnotetext{
is This study was supported by NIOSH grants R01 OHO7366-01 and R01 OHO7366-01S. The authors wish to thank: (a) other contributing members of the study team (in alphabetical order): Louiza Bloomstein, Vanessa Costa, Ruth Lederman, Maribel Melendez, Deepa Naishadham, Michael Ostler, Elizabeth Pratt, Roona Ray, Grace Sembajwe, David Wilson, and Richard Youngstrom; (b) our union and worksite collaborators; and (c) the workers who shared their experiences with us by participating in this study.

* Corresponding author. Tel.: +1617432 1571; fax: +1617432 3123.

E-mail address: nkrieger@hsph.harvard.edu (N. Krieger).

1 At time of study: Center for Community-Based Research, Dana-Farber Cancer Institute, 44 Binney Street, Boston, MA 02115, USA.

2 At time of study: Harvard School of Public Health and Center for Community-Based Research, Dana-Farber Cancer Institute, 44 Binney Street, Boston, MA 02115, USA.
} 
of adverse exposures, limiting the ability to detect significant associations. As clarified by the "inverse hazard law," to understand health inequities, research is needed that contrasts exposures and health status population-wide, not just among those most inequitably exposed.

(c) 2008 Elsevier Ltd. All rights reserved.

In 1971, Julian Tudor Hart famously penned the "inverse care law": "The availability of good medical care tends to vary inversely with the need for the population served" (Hart, 1971). Research on societal determinants of health likewise suggests the existence of an "inverse hazard law," which we define as: "The accumulation of health hazards tends to vary inversely with the power and resources of the populations affected." Clustered together and embodied conjointly (Krieger, 2004), these health hazards include economic deprivation, discrimination, and hazardous living and working conditions, harming the health of societal groups exposed to - as compared to those who are buffered from, and often benefit from - these inequities (Krieger, 2004; Levy \& Sidel, 2006).

As a case in point, research indicates that in the United States low-compared to high-wage workers are more likely to be exposed to occupational hazards, have less job autonomy, have less or no coverage for health insurance, fewer resources to live a healthy life, and are more likely to be persons of color and women, reflecting past and present patterns of racial/ethnic and gender discrimination (Baron \& Dorsey, 2006). Yet, to date, scant research has focused on the combined health impact of social and occupational hazards at work (Lipscomb, Loomis, McDonald, Argue, \& Wing, 2006; Quinn, 2003).

We accordingly designed the United for Health study to investigate the joint distribution and health implications of occupational (dust, fumes, chemical, noise, ergonomic strain) and social (racial discrimination, sexual harassment, workplace abuse) hazards in a US population of predominantly low-wage white, black, and Latino women and men unionized workers. In prior publications, we have reported on this cohort's high levels of exposures to economic deprivation and both social (Krieger et al., 2006) and occupational (Quinn et al., 2007) hazards; a sub-sample analysis documented associations between racial discrimination and both cigarette smoking and psychological distress (Krieger, Smith, Naishadham, Hartman, \& Barbeau, 2005). In this paper, we analyze associations between the workers' blood pressure and their exposure to social and occupational hazards. Fig. 1 presents our conceptual model. It is premised on an ecosocial analysis of embodying inequality in relation to pathways, levels, and lifecourse (Krieger, 1994, 2004), with the specific content informed by research on social, physical, occupational, behavioral, and anthropometric determinants of blood pressure, their societal distribution, and social disparities in blood pressure (Baron \& Dorsey, 2006; Huang \& Ghio, 2006; Kasl, 1996; Krieger, 1999; Lundberg, 2002; Pickering, 2001; Talbott, Gibson, Burks, Engberg, \& McHugh, 1999; Wyatt et al., 2003).

\section{Study population and methods}

\section{Study population and protocol: the United for Health cohort}

As described in detail in our prior publications (Barbeau, Hartman, Quinn, Stoddard, \& Krieger, 2007; Krieger et al., 2005, 2006; Quinn et al., 2007), we recruited participants in the United for Health study from the rosters of union members employed in 14 worksites located in the greater Boston area in Massachusetts and variously engaged in meat processing, electrical light manufacturing, retail grocery stores, and school bus driving. The unions and management had no access to the study data and no role in the preparation, review, or approval of the study's scientific papers. The study incentive was either a 1 -h paid work-release plus a $\$ 25$ pre-paid grocery card (handed out after the survey was completed) or, if paid work-release was not an option, a $\$ 50$ pre-paid grocery card. All participants received an informed consent reference sheet and provided verbal informed consent. Conduct of the study was approved by the DanaFarber Cancer Institute's Office for the Protection of Research Subjects, the Human Subjects Committee of the Harvard School of Public Health, and the Institutional Review Board of the University of Massachusetts.

Recruitment took place between March 2003 and August 2004. Union members at each worksite were sent an introductory letter by the union. Study staff then screened, recruited, and administered the survey to the workers on-site. The 40-45 min survey was administered (either in English or Spanish) in a private room, followed by a 15-min health check. For the survey, we used audiocomputer assisted self-interviewing (ACASI), both to improve likelihood of obtaining sensitive information and to enable persons with low literacy to respond (Office of Applied Studies, 2001). The Spanish version of the survey was translated from English and then back-translated to ensure accuracy. One or more of the interview staff were bilingual in English and Spanish and were available to answer participants' questions.

Among the 2323 union members on the list we were given by the unions, 1776 stated that they met study eligibility criteria for age (25-64 years old) and length of employment (at least 2 months). Of these, 1282 (72\%) completed the survey, of whom 80 had an age that was either unknown or outside the eligible age range, yielding an analytic sample of 1202 age-eligible workers.

\section{Sociodemographic measures: individual-level and worksite}

We obtained self-reported data on race/ethnicity, gender, sexuality, age, nativity, and current and childhood socioeconomic position. All persons who self-identified as 


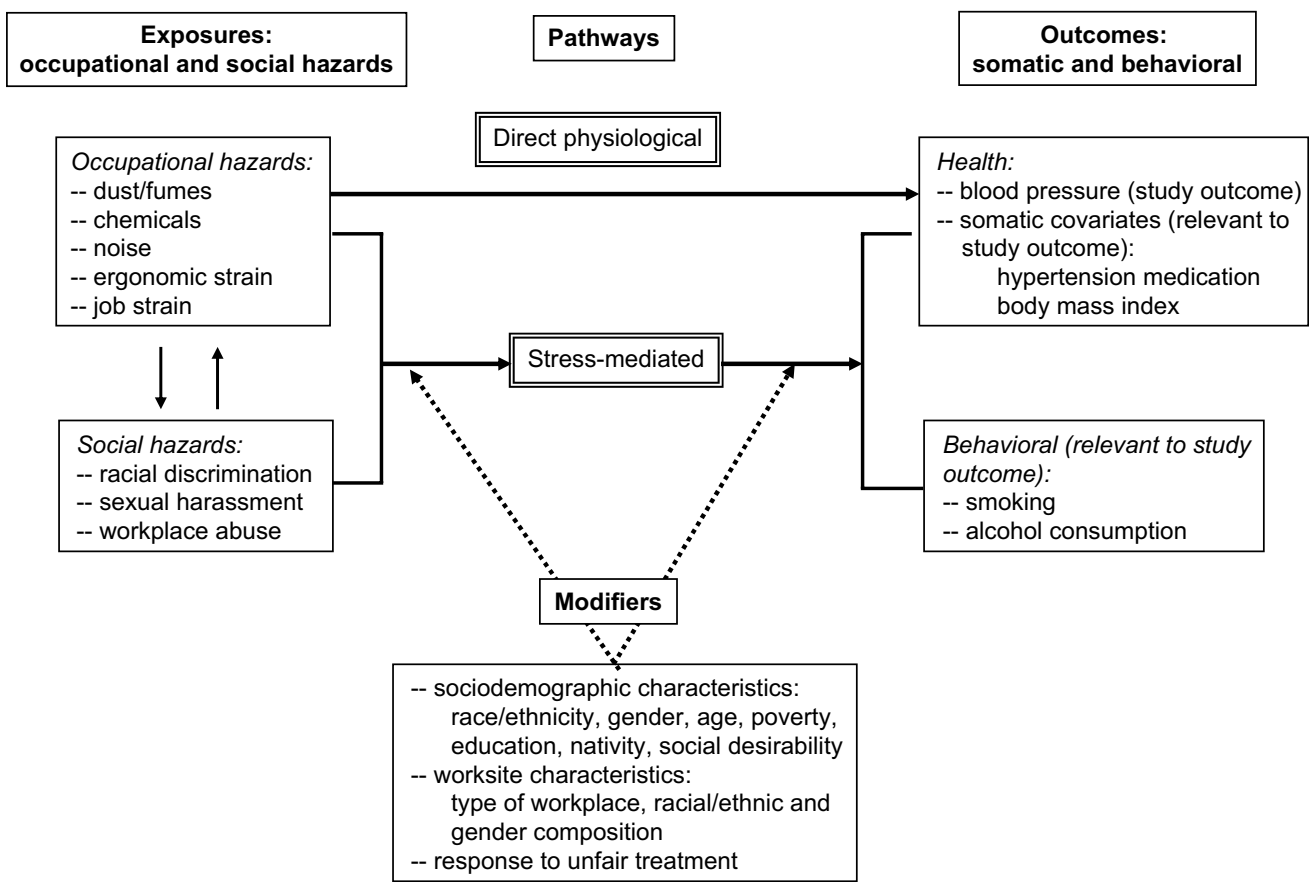

Fig. 1. Conceptual model for blood pressures analyses: United for Health study (Boston, MA, 2003-2004).

being Latino or Hispanic were categorized as such; the "white" and "black" designations refer only to nonHispanic white and black populations. We obtained data on the highest level of education attained by the respondents, their partners (if applicable), and their parents, and assessed income in relation to household poverty level, taking into account the number and age of persons in the household; in 2003, the US federal poverty line for a household of 2 adults and 2 children equaled \$18,660 (US Census Bureau, 2004). At the worksite level, we obtained data on the gender and racial/ethnic composition of the participants' coworkers and also worksite type (manufacturing, retail, transportation).

\section{Social hazard measures}

We included self-report measures for three social hazards: workplace abuse, sexual harassment, and racial discrimination (Krieger et al., 2006). To control for how self-presentation might affect these responses, we used a 5-item validated social desirability scale (Hays \& the RAND Corporation, 1989).

The measures of workplace abuse (reduced 8-item version of the Generalized Workplace Abuse (GWA) instrument (Richman et al., 1999)) and sexual harassment (5 items from two validated instruments (Fitzgerald, Gelfand, \& Drasgow, 1995; Richman et al., 1999)) referred to events in the past 12 months. Examples of workplace abuse included being yelled or sworn at; the sexual harassment instrument focused on sexual coercion, unwanted sexual attention, and gender-based hostility. Summary scores (recommended for analysis as continuous variables (Richman et al., 1999)) equaled the sum of items reported (workplace abuse: "never" $=0$, "once" $=1$, "more than once" $=2$, score range $=0-16$; sexual harassment: "no" $=0$, "yes" $=1$, score range $=0-5$ ).

To measure racial discrimination, we used the validated 9-item "Experiences of Discrimination" (EOD) questionnaire (Krieger et al., 2005, based on Krieger, 1990; Krieger \& Sidney, 1996), which employs a timeframe of "ever," reflecting how exposure can start in childhood and can have a cumulative as well as contemporaneous adverse impact on health (Krieger, 1999). We employed the more commonly used measure of number of domains $(0,1-2$, $3+)$ in which experiences of racial discrimination were reported (range: 0-9), rather than the frequency score, since the two measures yielded comparable findings.

\section{Occupational hazard measures}

Self-report data on workplace occupational hazards were based on 12-month recall period, using a 3-point scale corresponding to low, moderate, or high exposure, except for chemical and dust exposure, which used a 4-point scale to maintain comparability to prior studies (Quinn et al., 2007). Measures pertained to: (1) airborne dust, fumes, and chemicals (American Thoracic society questionnaire, European Community Respiratory Health Survey, 1993; Ferris, 1978); (2) noise ( $<3$, 3-6, or $>6$ h per shift spent in a noisy environment, assessed using Occupational Safety and Health Administration (American National Standards Institute, 1991) and World Health Organization (2001) guidelines); (3) ergonomic strain ( $<1$, $1-4,>4 \mathrm{~h}$ per shift involving strained postures in the shoulder, neck, and back or repetitive hand motions, assessed using the Washington State (2000) Ergonomics 
Rule, plus self-report on the heaviest objects lifted at work); and (4) job strain (adapted from the Karasek Job Content Questionnaire for demand-control (Karasek, 1985), with scores dichotomized at the national median value). High exposure equaled the top level for all occupational hazards except for: (a) dust and chemicals, for which we used the top two levels, and (b) job strain, where "high strain" equaled "high demand/low control" and other combinations were categorized as "low strain."

\section{Physical health exam}

After participants sat quietly for $5 \mathrm{~min}$, we used the Dinamap 8100 automated blood pressure recorder (Whincup, Bruce, Book, \& Shaper, 1992) to get 3 readings each for systolic and diastolic blood pressure; in our analyses, we used the average of the 3 measures. We next asked participants to remove their shoes and measured their height to the nearest half-inch and weight to the nearest pound and used these data to calculate body mass index $\left(\mathrm{BMI}=\right.$ weight $(\mathrm{kg}) /$ height $\left.\left(\mathrm{m}^{2}\right)\right)$. We also collected participants' self-report data on: having ever been told by a physician they had hypertension; current use of antihypertensive medication; and time (in hours and minutes) since their last cigarette, caffeinated beverage (coffee, tea, or soda), alcoholic beverage (beer, wine, or liquor), and food consumption. Virtually all current smokers (as categorized based on self-report survey data, using questions from 1997 NHIS Sample Adult Core Questionnaire (National Center for Health Statistics, 2007)) reported having smoked in the past $24 \mathrm{~h}$.

\section{Statistical analysis}

Statistical analysis of the data, conducted using SAS (SAS, 2001), was premised on our conceptual model (Fig. 1). We first described the distribution of the outcome, exposures, and covariates, overall and by race/ethnicity and gender, in the analytic dataset and also examined correlations between the social and occupational hazards. Although most variables had little missing data (usually under $1 \%$ to at most $5 \%$ ), for a few key covariates (e.g., adult poverty, educational level, and place of birth for Latinos), it equaled approximately 10\%; for a handful of others, e.g., concerning childhood socioeconomic conditions, it exceeded $20 \%$. To avoid problems posed by potentially invalid data, we restricted our analyses to key variables for which the overall percent missing did not exceed $10 \%$. Even so, among the remaining participants, 307 (26\%) were missing data on at least one key variable. To avoid bias and enhance statistical power, we employed multiple imputation (including on the individual items used to create summary scores for both the social and occupational hazards), using the Amelia II program (King, Honaker, Joseph, \& Scheve, 2001). We created 20 multiply imputed datasets based on an imputation model containing all variables from Table 1 and conducted all subsequent analyses (including combining results across imputations) in SAS.

The multivariable linear regression analyses investigated the associations between blood pressure (separately for systolic (SBP) and diastolic (DBP)) and the social and occupational hazards, controlling for relevant covariates; analogous logistic regression analyses used hypertension as the outcome (SBP $\geq 140 \mathrm{~mm} \mathrm{Hg}$ and/or DBP $\geq 90 \mathrm{~mm} \mathrm{Hg}$ and/or taking hypertension medication (Chobanian et al., 2003)). Based on bivariate analyses of each variable in relation to blood pressure, our series of multivariable analyses included: (1) only the sociodemographic variables; (2) only the social hazards (singly, then all 3 together); (3) only the occupational hazard summary score (since bivariate analyses of the individual occupational hazards showed the summary score to be an appropriate exposure measure); and (4) all covariates. We report results only for the "all covariate" model, since it most concisely and efficiently summarized the key findings. In these models, the beta coefficient can be interpreted as the difference in systolic blood pressure ( $\mathrm{mm} \mathrm{Hg}$ ) across comparison groups: for the categorical variables, the contrast is the comparison group vs. the specified referent group; for the continuous variables, the difference refers to the change in systolic blood pressure per unit change of the continuous predictor variable.

We conducted analyses first for the total population, controlling for race/ethnicity and gender, and second, stratified by race/ethnicity and gender. Given evidence of considerable of effect modification by race/ethnicity but less by gender (affecting solely sexual harassment and workplace abuse), we present results separately for the white, black and Latino workers, with models including an interaction term for gender with both sexual harassment and workplace abuse. We do not report blood pressure results for the 121 workers of other race/ethnicity (2 American Indian, 28 Asian, 1 South Asian, 1 Native Hawaiian, 77 "two or more races," and 12 "other") because small numbers precluded meaningful analysis. Given similar findings for SBP, DBP, and hypertension, we report only the SBP results. Initial analyses used a mixed model approach to account for clustering of workers within workplaces. Because results showed that, conditional on the covariates, there was negligible worksite clustering, we present results based on fixed effect models, ignoring worksite.

\section{Results}

Table 1 shows the distribution of the outcome and selected exposures and key covariates among the 1202 members of the United for Health cohort, overall and by race/ethnicity, prior to imputing missing values. As presented in more detail in Supplemental Table 1 and in our previous papers (Barbeau et al., 2007; Krieger et al., 2005, 2006), the findings reveal high levels of economic deprivation and of exposure to social and occupational hazards (79\% to at least 1 social hazard, $82 \%$ to at least 1 occupational hazard) among this cohort of predominantly lowincome multi-racial/ethnic working class women and men, of whom fully $40 \%$ were below the US poverty line ( $24 \%$ of whites vs. 40-50\% among the black, Latino, and other workers of color). Among all workers, the average systolic blood pressure equaled $134.8 \mathrm{~mm} \mathrm{Hg}$ and about $21 \%$ of the workers were hypertensive (ranging from 6\% among 
Table 1

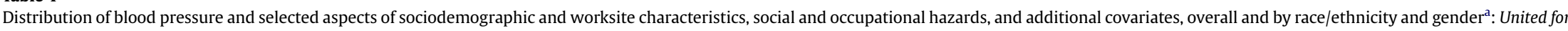
Health study, Boston, MA (USA), 2003-2004

\begin{tabular}{|c|c|c|c|c|c|c|c|c|c|}
\hline \multirow[t]{2}{*}{ Characteristics } & \multirow{2}{*}{$\frac{\text { Total }^{\mathrm{a}}}{\text { All }(N=1202)}$} & \multicolumn{2}{|l|}{ Black $^{\mathrm{a}}$} & \multicolumn{2}{|l|}{ Latino $^{\mathrm{a}}$} & \multicolumn{2}{|l|}{ White $^{\mathrm{a}}$} & \multicolumn{2}{|c|}{ Other race/ethnicity ${ }^{\mathrm{a}}$} \\
\hline & & $\begin{array}{l}\text { Men } \\
(N=308)\end{array}$ & $\begin{array}{l}\text { Women } \\
(N=158)\end{array}$ & $\begin{array}{l}\text { Men } \\
(N=152)\end{array}$ & $\begin{array}{l}\text { Women } \\
(N=115)\end{array}$ & $\begin{array}{l}\text { Men } \\
(N=182)\end{array}$ & $\begin{array}{l}\text { Women } \\
(N=102)\end{array}$ & $\begin{array}{l}\text { Men } \\
(N=73)\end{array}$ & $\begin{array}{l}\text { Women } \\
(N=45)\end{array}$ \\
\hline \multicolumn{10}{|l|}{ Blood pressure } \\
\hline $\begin{array}{l}\text { Systolic blood } \\
\text { pressure: mean (SD) (mm Hg) }\end{array}$ & $134.8(17.9)$ & $138.5(18.0)$ & $134.6(18.7)$ & $132.7(15.4)$ & $125.7(19.6)$ & $138.1(16.4)$ & $129.1(16.9)$ & $137.1(17.8)$ & $131.8(15.8)$ \\
\hline $\begin{array}{l}\text { Diastolic blood } \\
\quad \text { pressure: mean (SD) (mm Hg) }\end{array}$ & $78.6(12.9)$ & $82.5(12.9)$ & $77.8(11.7)$ & $76.9(11.8)$ & $70.4(14.1)$ & $81.9(12.3)$ & $73.6(11.9)$ & $79.8(10.0)$ & $74.4(13.1)$ \\
\hline Missing (\%) & 4.8 & 0.7 & 2.5 & 16.5 & 15.7 & 0.6 & 1.0 & 4.1 & 2.2 \\
\hline Hypertensive (\%) & 20.9 & 27.3 & 22.2 & 9.9 & 6.1 & 28.0 & 19.6 & 17.8 & 15.6 \\
\hline Missing (\%) & 4.7 & 0.7 & 1.9 & 16.5 & 15.7 & 0.6 & 1.0 & 2.7 & 2.2 \\
\hline $\begin{array}{l}\text { Hypertensive medication } \\
\text { (\%): yes }\end{array}$ & 17.4 & 21.1 & 24.7 & 7.9 & 4.4 & 15.9 & 12.8 & 26.0 & 22.2 \\
\hline \multicolumn{10}{|c|}{ Sociodemographic and worksite characteristics } \\
\hline \multicolumn{10}{|l|}{ Age (\%) } \\
\hline $24-44$ years & 49.3 & 38.3 & 55.1 & 64.5 & 68.7 & 39.6 & 45.1 & 48.0 & 62.2 \\
\hline 45-64 years & 50.7 & 61.7 & 44.9 & 35.5 & 31.3 & 60.4 & 54.9 & 52.1 & 37.8 \\
\hline Nativity (\%): born in US state or territory & 47.8 & 27.0 & 67.7 & 27.0 & 24.4 & 86.8 & 92.3 & 27.4 & 44.4 \\
\hline $\begin{array}{l}\text { Poverty level } \\
\text { (household) }(\%):<100 \% \text { poverty }\end{array}$ & 40.4 & 46.8 & 48.7 & 46.7 & 56.5 & 21.4 & 29.4 & 32.9 & 48.9 \\
\hline Education (respondent) $(\%):<12$ th grade & 22.8 & 20.1 & 15.2 & 35.5 & 36.5 & 20.3 & 20.6 & 12.3 & 28.9 \\
\hline \multicolumn{10}{|l|}{ Type of worksite (\%) } \\
\hline Manufacturing & 29.0 & 2.3 & 2.5 & 73.0 & 70.4 & 40.7 & 25.5 & 23.3 & 15.6 \\
\hline Retail & 32.6 & 18.5 & 54.4 & 16.5 & 25.2 & 41.2 & 64.7 & 21.9 & 55.6 \\
\hline Transportation & 38.4 & 79.2 & 43.0 & 10.5 & 4.4 & 18.1 & 9.8 & 54.8 & 28.9 \\
\hline \multicolumn{10}{|l|}{$\begin{array}{l}\text { Worksite gender } \\
\text { composition of coworkers (\%) }\end{array}$} \\
\hline Mostly men & 36.2 & 55.5 & 36.1 & 21.7 & 5.2 & 45.1 & 19.6 & 45.2 & 20.0 \\
\hline Mostly women & 13.3 & 6.5 & 12.7 & 19.7 & 25.2 & 10.4 & 11.8 & 17.8 & 13.3 \\
\hline About even & 50.0 & 37.7 & 50.0 & 58.6 & 69.6 & 44.5 & 68.6 & 35.6 & 66.7 \\
\hline \multicolumn{10}{|l|}{$\begin{array}{l}\text { Worksite racial/ethnic } \\
\text { composition of coworkers (\%) }\end{array}$} \\
\hline Mostly same race/ethnicity & 25.6 & 30.5 & 24.1 & 27.6 & 32.2 & 21.4 & 9.8 & 34.2 & 22.2 \\
\hline Mostly different race/ethnicity & 46.7 & 43.5 & 50.6 & 39.5 & 33.0 & 50.0 & 58.8 & 49.3 & 53.3 \\
\hline About even & 27.4 & 26.0 & 24.7 & 32.9 & 33.9 & 28.6 & 31.4 & 16.4 & 24.4 \\
\hline \multicolumn{10}{|l|}{ Social hazards } \\
\hline $\begin{array}{l}\text { Reported at least } 1 \text { type } \\
\text { of workplace abuse (\%) }\end{array}$ & 70.1 & 66.6 & 71.5 & 66.4 & 62.6 & 84.1 & 80.4 & 65.8 & 66.7 \\
\hline $\begin{array}{l}\text { Workplace abuse } \\
\text { summary score: mean (SD) }\end{array}$ & $4.9(4.0)$ & $3.2(3.9)$ & $3.9(3.8)$ & $3.8(4.1)$ & $3.1(3.8)$ & $5.3(4.3)$ & $4.4(3.5)$ & $4.3(4.6)$ & $3.6(3.8)$ \\
\hline $\begin{array}{l}\text { Reported at least } 1 \text { type } \\
\text { of sexual harassment (\%) }\end{array}$ & 23.1 & 25.3 & 27.2 & 21.0 & 17.4 & 19.2 & 19.6 & 24.7 & 33.3 \\
\hline $\begin{array}{l}\text { Sexual harassment } \\
\text { summary score: mean (SD) }\end{array}$ & $0.4(0.9)$ & $0.4(0.9)$ & $0.5(1.0)$ & $0.4(0.9)$ & $0.3(0.9)$ & $0.3(0.6)$ & $0.3(0.6)$ & $0.6(1.4)$ & $0.5(0.8)$ \\
\hline $\begin{array}{l}\text { Racial discrimination: } \\
\text { situations mentioned (\%): } 3+\end{array}$ & 28.4 & 46.4 & 35.4 & 28.9 & 13.9 & 10.4 & 8.8 & 39.7 & 22.2 \\
\hline $\begin{array}{l}\text { Racial discrimination } \\
\text { summary score: mean (SD) }\end{array}$ & $1.9(2.4)$ & $3.0(2.9)$ & $2.4(2.5)$ & $1.8(2.3)$ & $1.0(1.6)$ & $0.8(1.4)$ & $0.8(1.4)$ & $2.5(2.7)$ & $1.7(2.0)$ \\
\hline
\end{tabular}


Occupational hazards: high exposure (\%)

Dust

Chemicals

Noise

Ergonomic strain: shoulder

Ergonomic strain: neck

Ergonomic strain: back

Ergonomic strain:

hand repetition

Ergonomic strain:

heavy lifting

Combined occupational

exposures: high

exposure (\%)

$1-2$

3-4

$5+$

Job strain

(\%): high exposure

\section{Additional covariate}

Response to unfair treatment

Act/talk

Act/quiet

Accept/talk

Social desirability:

mean (SD)

mean (SD)

index $\left(\mathrm{kg} / \mathrm{m}^{2}\right)$ : mean (SD)

Hypertensive medication

(\%): yes

Smoking (\%): current

Alcohol consumption

in past $24 \mathrm{~h}(\%)$ : yes

\begin{tabular}{|c|c|c|c|c|c|c|c|c|}
\hline 42.1 & 41.6 & 48.7 & 37.5 & 34.8 & 41.2 & 54.9 & 43.8 & 48.9 \\
\hline 10.7 & 9.7 & 7.6 & 13.2 & 13.9 & 12.1 & 9.8 & 5.5 & 11.1 \\
\hline 23.6 & 24.7 & 27.2 & 21.7 & 20.9 & 23.6 & 22.6 & 26.0 & 26.7 \\
\hline 17.6 & 19.8 & 12.0 & 19.1 & 23.5 & 20.9 & 9.8 & 19.2 & 11.1 \\
\hline $37.2(31.8)$ & $38.5(30.7)$ & $51.1(34.1)$ & $35.7(31.0)$ & $34.0(30.0)$ & $28.0(29.9)$ & $41.0(32.5)$ & $28.1(29.4)$ & $36.8(30.0)$ \\
\hline $29.4(6.1)$ & $28.3(4.6)$ & $32.9(8.5)$ & $28.3(4.9)$ & $28.9(5.8)$ & $29.7(6.0)$ & $29.1(7.2)$ & $28.4(4.4)$ & $28.8(6.4)$ \\
\hline 17.4 & 21.1 & 24.7 & 7.9 & 4.4 & 15.9 & 12.8 & 26.0 & 22.2 \\
\hline 22.7 & 16.2 & 16.5 & 21.1 & 15.7 & 32.4 & 50.0 & 19.2 & 17.8 \\
\hline 10.2 & 8.1 & 8.2 & 5.9 & 1.7 & 27.5 & 11.8 & 6.9 & 0.0 \\
\hline
\end{tabular}

Note: column percent are based on distributions including "missing" as a category; for detailed distributions, include percent missing, see Supplemental Table 1.

a Data on the 1202 workers include the 38 with data missing on race/ethnicity and the 29 with data missing on gender. The data shown by race/ethnicity and gender do not include: among the 480 total black

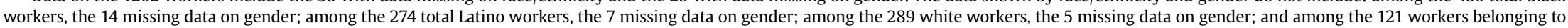
other racial/ethnic groups, the 3 missing data on gender.

$\begin{array}{rrrrrrr}30.4 & 33.6 & 20.0 & 38.5 & 47.1 & 32.9 & 24.4 \\ 26.6 & 27.6 & 15.7 & 32.4 & 31.4 & 21.9 & 17.8 \\ 15.8 & 46.1 & 44.4 & 33.0 & 31.4 & 34.3 & 8.9 \\ 22.8 & 28.3 & 28.7 & 15.4 & 23.5 & 26.0 & 22.2 \\ 32.9 & 47.4 & 52.2 & 39.0 & 47.1 & 34.3 & 35.6 \\ 22.2 & 46.7 & 40.0 & 36.3 & 40.2 & 28.8 & 33.3 \\ 26.6 & 36.8 & 33.9 & 38.5 & 47.1 & 19.2 & 33.3 \\ 14.6 & 31.6 & 17.4 & 33.0 & 31.4 & 12.3 & 24.4\end{array}$

$\begin{array}{rr}19.6 & 6.6 \\ 34.8 & 32.9 \\ 25.3 & 32.2 \\ 8.9 & 21.7 \\ 36.1 & 19.1\end{array}$

$\begin{array}{ll}12.2 & 11.0 \\ 33.0 & 38.5 \\ 33.0 & 30.2 \\ 13.9 & 18.1 \\ 27.0 & 39.0\end{array}$

11.8
32.4
32.4
23.5
43.1

19.2

38.4

23.3

30. 
Latinas to $28 \%$ among white men), with a similar proportion taking medication for hypertension.

Table 2 presents Pearson correlations between the social and occupational hazards. Statistically significant correlations $(p<0.05)$ were especially evident between: (a) racial discrimination and workplace abuse, among the workers of color; (b) racial discrimination and sexual harassment, among the women workers; and (c) workplace abuse and high exposure to occupational hazards, among all workers. Only among black men was the correlation significant between high exposure to occupational hazards and racial discrimination. In all cases, the significant correlations ranged between 0.2 and 0.5 (indicating an association, but not co-linearity), with correlations above 0.35 occurring only among workers of color.

Table 3 presents the analytic results for associations between SBP and the specified variables, overall and by race/ethnicity. Key findings for the total population are as follows. First, as expected, adjusting for covariates notably altered the bivariate results, including slightly increasing the difference in SBP among blacks compared to whites (by 1.3 points), further decreasing the SBP of women compared to men (by 2.5 points), and reducing the Latinos' initially statistically significant 5.3 point lower SBP compared to whites to 1.0 , a non-significant difference. Covariates significantly associated with elevated SBP in the multivariable analyses thus included: race/ethnicity (but only for black vs. white comparisons (3.5 $\mathrm{mm} \mathrm{Hg}, 95 \% \mathrm{CI} \mathrm{0.3,6.7));}$ gender (men higher than women by $8.8 \mathrm{~mm} \mathrm{Hg}, 95 \%$ CI 5.7 , 11.8); age (by year, $0.4 \mathrm{~mm} \mathrm{Hg}, 95 \% \mathrm{CI} 0.3,0.5$ ); BMI (by unit, $0.7,95 \% \mathrm{CI} 0.5,0.8)$; hypertension medication $(7.4 \mathrm{~mm} \mathrm{Hg}$, 95\% CI 4.7, 10.0); and alcohol (5.1 mm Hg; 95\% CI 1.9, 8.4). The interaction of sexual harassment and gender was statistically significant (higher for women, by $2.8 \mathrm{~mm} \mathrm{Hg}$ $95 \%$ CI $0.6,5.0)$. A protective effect for workers in transportation compared to retail (by $3.4 \mathrm{~mm} \mathrm{Hg}, 95 \% \mathrm{CI} 0.5,6.4$ ) was also evident. Weaker associations with elevated SBP occurred for lower vs. higher education, and for responding to unfair treatment by accepting it as a fact of life and keeping it to oneself, vs. taking action and talking to others. No significant associations were evident for poverty, racial discrimination, workplace abuse, occupational hazards, social desirability, nativity, job control, co-worker gender, or co-worker race/ethnicity. Given the lack of a main effect for the occupational hazards, we did not model the interaction of social and occupational hazards on SBP.

Analyses stratified by race/ethnicity yielded similar results, albeit with three differences. First, the interaction of sexual harassment and gender was strongest in the white population $(6.3 \mathrm{~mm} \mathrm{Hg}, 95 \% \mathrm{CI} 0.8,11.8)$ but similarly

Table 2

Pearson correlations between the social and occupational hazards, ${ }^{a}$ by racial/ethnic-gender group: $\rho$ ( $p$-value*), United for Health study (Boston, MA, 20032004)

\begin{tabular}{|c|c|c|c|c|c|c|}
\hline Hazard & Race/ethnicity & Gender & Workplace abuse & Sexual harassment & Racial discrimination & $\begin{array}{l}\text { High exposure } \\
\text { to occupational hazards }\end{array}$ \\
\hline Workplace abuse & $\begin{array}{l}\text { Black } \\
\text { Latino } \\
\text { White } \\
\text { Additional race/ethnicity }\end{array}$ & $\begin{array}{l}\text { Men } \\
\text { Women } \\
\text { Men } \\
\text { Women } \\
\text { Men } \\
\text { Women } \\
\text { Men } \\
\text { Women }\end{array}$ & $\begin{array}{l}1.00 \\
1.00 \\
1.00 \\
1.00 \\
1.00 \\
1.00 \\
1.00 \\
1.00\end{array}$ & & & \\
\hline Sexual harassment & $\begin{array}{l}\text { Black } \\
\text { Latino } \\
\text { White } \\
\text { Additional race/ethnicity }\end{array}$ & $\begin{array}{l}\text { Men } \\
\text { Women } \\
\text { Men } \\
\text { Women } \\
\text { Men } \\
\text { Women } \\
\text { Men } \\
\text { Women }\end{array}$ & $\begin{array}{c}\mathbf{0 . 1 7}(<\mathbf{0 . 0 1}) \\
\mathbf{0 . 2 4}(<\mathbf{0 . 0 1}) \\
0.07(0.43) \\
\mathbf{0 . 2 6}(\mathbf{0 . 0 1}) \\
0.06(0.43) \\
0.12(0.23) \\
-0.07(0.56) \\
0.05(0.77)\end{array}$ & $\begin{array}{l}1.00 \\
1.00 \\
1.00 \\
1.00 \\
1.00 \\
1.00 \\
1.00 \\
1.00\end{array}$ & & \\
\hline Racial discrimination & $\begin{array}{l}\text { Black } \\
\text { Latino } \\
\text { White } \\
\text { Additional race/ethnicity }\end{array}$ & $\begin{array}{l}\text { Men } \\
\text { Women } \\
\text { Men } \\
\text { Women } \\
\text { Men } \\
\text { Women } \\
\text { Men } \\
\text { Women }\end{array}$ & $\begin{array}{l}0.36(<0.01) \\
0.38(<0.01) \\
0.44(<0.01) \\
0.49(<0.01) \\
0.20(0.01) \\
0.08(0.44) \\
0.52(<0.01) \\
0.46(<0.01)\end{array}$ & $\begin{array}{l}0.07(0.24) \\
0.28(<\mathbf{0 . 0 1}) \\
0.10(0.24) \\
0.39(<\mathbf{0 . 0 1}) \\
0.28(<0.01) \\
0.35(<\mathbf{0 . 0 1}) \\
0.32(\mathbf{0 . 0 1}) \\
0.33(\mathbf{0 . 0 3})\end{array}$ & $\begin{array}{l}1.00 \\
1.00 \\
1.00 \\
1.00 \\
1.00 \\
1.00 \\
1.00 \\
1.00\end{array}$ & \\
\hline $\begin{array}{l}\text { High exposure } \\
\text { to occupational hazards }\end{array}$ & $\begin{array}{l}\text { Black } \\
\text { Latino } \\
\text { White } \\
\text { Additional race/ethnicity }\end{array}$ & $\begin{array}{l}\text { Men } \\
\text { Women } \\
\text { Men } \\
\text { Women } \\
\text { Men } \\
\text { Women } \\
\text { Men } \\
\text { Women }\end{array}$ & $\begin{array}{l}0.26(<0.01) \\
0.19(0.02) \\
0.27(<0.01) \\
0.22(0.02) \\
0.29(<0.01) \\
0.07(0.51) \\
0.38(<\mathbf{0 . 0 1}) \\
0.30(0.05)\end{array}$ & $\begin{array}{r}0.05(0.40) \\
0.03(0.75) \\
-0.02(0.77) \\
0.00(0.96) \\
-0.09(0.24) \\
0.15(0.14) \\
0.04(0.76) \\
0.10(0.51)\end{array}$ & $\begin{array}{l}\mathbf{0 . 3 5}(<\mathbf{0 . 0 1}) \\
0.13(0.12) \\
\mathbf{0 . 1 6}(\mathbf{0 . 0 4}) \\
0.13(0.15) \\
0.11(0.16) \\
0.11(0.27) \\
0.22(0.06) \\
0.24(0.11)\end{array}$ & $\begin{array}{l}1.00 \\
1.00 \\
1.00 \\
1.00 \\
1.00 \\
1.00 \\
1.00 \\
1.00\end{array}$ \\
\hline
\end{tabular}

${ }^{*}$ Correlations with $p<0.05$ noted in bold.

a The correlations are based on the summary score for each of the social hazards and the composite high-exposure occupational hazard score. 
Table 3

Association of systolic blood pressure with social and occupational hazards: United for Health study (Boston, MA, 2003-2004)

\begin{tabular}{|c|c|c|c|c|c|c|c|c|c|c|c|}
\hline \multirow[t]{3}{*}{ Variable } & & \multicolumn{10}{|c|}{ Systolic blood pressure (difference in $\mathrm{mm} \mathrm{Hg}$ ): $\widehat{\beta}$ parameter estimate (95\% confidence interval) } \\
\hline & & \multicolumn{4}{|c|}{ Total population $(N=1202)$} & \multicolumn{2}{|c|}{ White $(N=300)$} & \multicolumn{2}{|c|}{ Black $(N=493)$} & \multicolumn{2}{|c|}{ Latino $(N=286)$} \\
\hline & & \multicolumn{2}{|c|}{ Bivariate } & \multicolumn{2}{|c|}{ Multivariable $^{\mathrm{a}}$} & \multicolumn{2}{|c|}{ Multivariable $^{\mathrm{a}}$} & \multicolumn{2}{|c|}{ Multivariable $^{a}$} & \multicolumn{2}{|c|}{ Multivariable $^{\mathrm{a}}$} \\
\hline \multirow[t]{4}{*}{ Race/ethnicity } & White (referent [ref]) & & & & & & & & & & \\
\hline & Black & 2.20 & $(-0.36,4.76)$ & 3.52 & $(0.34,6.23)$ & & & & & & \\
\hline & Latino & -5.29 & $(-8.37,-2.22)$ & -1.05 & $(-4.57,2.47)$ & & & & & & \\
\hline & Other & 0.30 & $(-3.45,4.04)$ & 3.08 & $(-0.86,7.03)$ & & & & & & \\
\hline \multirow[t]{2}{*}{ Gender } & Men (ref) & & & & & & & & & & \\
\hline & Women & -6.29 & $(-8.39,-4.19)$ & -8.75 & $(-11.78,-5.71)$ & -8.14 & $(-14.54,-1.74)$ & -8.76 & $(-13.91,-3.62)$ & -6.92 & $(-13.14,-0.70)$ \\
\hline \multirow[t]{2}{*}{ Poverty } & No ( $\geq 100 \%$ poverty) (ref) & & & & & & & & & & \\
\hline & Yes $(<100 \%$ poverty $)$ & 1.42 & $(-0.79,3.63)$ & -0.68 & $(-2.81,1.45)$ & 0.80 & $(-3.64,5.23)$ & -0.43 & $(-3.72,2.87)$ & 0.62 & $(-4.11,5.35)$ \\
\hline \multirow[t]{2}{*}{ Education } & $\begin{array}{l}<\text { High school }(\mathrm{HS}) \\
\geq \mathrm{HS},<4 \text { yrs college (ref) }\end{array}$ & 1.36 & $(-1.18,3.90)$ & 1.83 & $(-0.56,4.21)$ & 5.53 & $(0.83,10.22)$ & 1.09 & $(-2.89,5.07)$ & 0.27 & $(-4.49,5.02)$ \\
\hline & $4+$ yrs college & -0.43 & $(-3.94,3.09)$ & 0.12 & $(-3.10,3.35)$ & -2.09 & $(-7.94,3.75)$ & 1.05 & $(-4.35,6.44)$ & -0.08 & $(-7.75,7.59)$ \\
\hline Sexual harassment & & 0.22 & $(-0.91,1.36)$ & -0.46 & $(-1.78,0.87)$ & -5.35 & $(-8.86,-1.85)$ & 0.20 & $(-1.87,2.28)$ & 1.14 & $(-2.22,4.50)$ \\
\hline Sexual harassment $\times$ gender & & & & 2.75 & $(0.56,4.95)$ & 6.30 & $(0.81,11.79)$ & 2.50 & $(-1.02,6.01)$ & 2.55 & $(-2.47,7.57)$ \\
\hline \multirow[t]{3}{*}{ Racial discrimination } & never (ref) & & & & & & & & & & \\
\hline & 1-2 exposures & 1.69 & $(-0.94,4.32)$ & 1.48 & $(-1.00,3.97)$ & -0.61 & $(-4.85,3.64)$ & 3.82 & $(-0.63,8.27)$ & 1.49 & $(-3.56,6.53)$ \\
\hline & $3+$ exposures & 0.16 & $(-2.25,2.57)$ & -1.19 & $(-3.72,1.35)$ & 2.43 & $(-4.19,9.06)$ & 1.52 & $(-2.46,5.50)$ & -3.74 & $(-9.73,2.26)$ \\
\hline Workplace abuse & & -0.13 & $(-0.38,0.12)$ & -0.16 & $(-0.47,0.16)$ & 0.16 & $(-0.39,0.72)$ & -0.39 & $(-0.93,0.16)$ & 0.07 & $(-0.71,0.86)$ \\
\hline Workplace abuse $\times$ gender & & & & 0.24 & $(-0.26,0.75)$ & -0.01 & $(-1.01,0.99)$ & 0.43 & $(-0.43,1.30)$ & -0.32 & $(-1.47,0.83)$ \\
\hline \multirow[t]{4}{*}{ Occupational hazards } & 0 exposures (ref) & & & & & & & & & & \\
\hline & 1-2 exposures & -1.09 & $(-4.16,1.97)$ & -0.76 & $(-3.63,2.10)$ & 1.74 & $(-4.67,8.14)$ & -2.23 & $(-6.25,1.79)$ & 0.87 & $(-7.23,8.96)$ \\
\hline & 3-4 exposures & -2.06 & $(-5.20,1.09)$ & -0.77 & $(-3.77,2.23)$ & 1.32 & $(-5.15,7.79)$ & -0.20 & $(-4.78,4.38)$ & 0.22 & $(-7.62,8.06)$ \\
\hline & $5+$ exposures & -2.58 & $(-6.30,1.13)$ & -0.72 & $(-4.38,2.93)$ & 0.98 & $(-6.13,8.09)$ & 1.28 & $(-4.94,7.50)$ & -4.00 & $(-12.53,4.53)$ \\
\hline Age & & 0.51 & $(0.41,0.61)$ & 0.42 & $(0.31,0.53)$ & 0.26 & $(0.05,0.47)$ & 0.58 & $(0.38,0.79)$ & 0.35 & $(0.09,0.61)$ \\
\hline Body mass index & & 0.63 & $(0.46,0.80)$ & 0.65 & $(0.49,0.82)$ & 0.88 & $(0.58,1.18)$ & 0.50 & $(0.24,0.77)$ & 0.58 & $(0.15,1.01)$ \\
\hline \multirow[t]{2}{*}{ Hypertension medicine } & No (ref) & & & & & & & & & & \\
\hline & Yes & 11.65 & $(9.07,14.24)$ & 7.35 & $(4.71,9.98)$ & 3.26 & $(-1.92,8.44)$ & 10.26 & $(6.36,14.15)$ & 8.85 & $(0.52,17.17)$ \\
\hline \multirow[t]{3}{*}{ Smoking } & Never (ref) & & & & & & & & & & \\
\hline & Ex & 3.21 & $(0.34,6.07)$ & -1.48 & $(-4.28,1.31)$ & 0.10 & $(-5.00,5.20)$ & -0.82 & $(-5.57,3.93)$ & 1.08 & $(-6.30,8.47)$ \\
\hline & Current & -0.38 & $(-2.89,2.13)$ & -0.42 & $(-2.90,2.07)$ & -0.97 & $(-4.91,3.36)$ & 0.51 & $(-4.04,5.05)$ & -3.81 & $(-9.83,2.21)$ \\
\hline \multirow[t]{2}{*}{ Alcohol } & No (not in past $24 \mathrm{~h}$ ) (ref) & & & & & & & & & & \\
\hline & Yes (in past $24 \mathrm{~h}$ ) & 4.82 & $(1.50,8.14)$ & 5.14 & $(1.91,8.37)$ & 4.02 & $(-0.36,8.40)$ & 2.18 & $(-3.99,8.36)$ & 7.60 & $(-2.09,17.28)$ \\
\hline Social desirability & & 0.01 & $(-0.02,0.04)$ & 0.01 & $(-0.03,0.04)$ & 0.08 & $(0.02,0.14)$ & -0.03 & $(-0.08,0.03)$ & 0.03 & $(-0.04,0.11)$ \\
\hline \multirow[t]{2}{*}{ Nativity } & US born (ref) & & & & & & & & & & \\
\hline & Foreign born & -1.39 & $(-3.41,0.63)$ & -0.29 & $(-2.19,2.76)$ & 0.06 & $(-5.81,5.94)$ & 2.24 & $(-2.10,6.57)$ & -1.41 & $(-6.55,3.73)$ \\
\hline Job control & High (ref) & & & & & & & & & & \\
\hline & Low & 0.36 & $(-1.90,2.61)$ & 0.91 & $(-1.20,3.02)$ & -0.72 & $(-4.48,3.05)$ & 1.18 & $(-2.33,4.69)$ & 1.94 & $(-3.62,7.49)$ \\
\hline Workplace & Retail (ref) & & & & & & & & & & \\
\hline & Manufacturing & -1.61 & $(-4.16,0.95)$ & -0.53 & $(-3.39,2.34)$ & 0.77 & $(-3.48,5.02)$ & -3.16 & $(-13.91,7.59)$ & 2.96 & $(-2.70,8.61)$ \\
\hline & Transportation & 4.11 & $(1.72,6.49)$ & -3.43 & $(-6.37,-0.48)$ & 2.52 & $(-3.57,8.61)$ & -7.85 & $(-12.67,-3.03)$ & -1.22 & $(-10.25,7.81)$ \\
\hline Co-worker gender & About even (ref) & & & & & & & & & & \\
\hline & Mostly men & 3.22 & $(0.94,5.51)$ & 1.06 & $(-1.35,3.47)$ & 0.90 & $(-3.54,5.35)$ & 1.48 & $(-2.27,5.23)$ & 0.45 & $(-5.81,6.70)$ \\
\hline & Mostly women & -1.54 & $(-4.77,1.68)$ & -1.64 & $(-4.65,1.36)$ & -4.20 & $(-10.10,1.70)$ & -1.26 & $(-7.23,4.70)$ & -1.29 & $(-6.89,4.31)$ \\
\hline
\end{tabular}

.




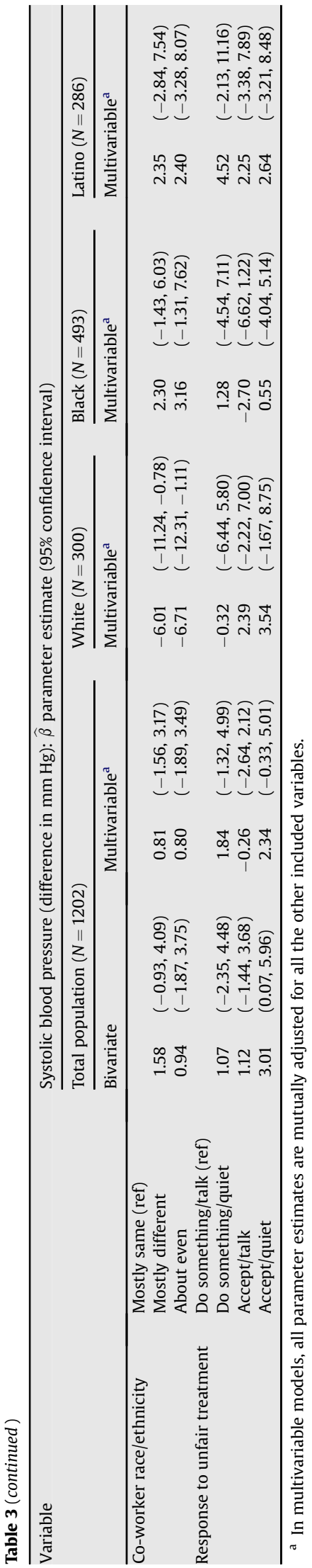

weaker among the black $(2.5 \mathrm{~mm} \mathrm{Hg}, 95 \% \mathrm{CI}-1.02$, 6.01) and Latina $(2.6 \mathrm{~mm} \mathrm{Hg}, 95 \% \mathrm{CI}-2.5,7.8)$ populations. Second, the association of SBP with hypertension medication was much greater among the black and Latino compared to white workers (10.3 and 8.8 vs. $3.3 \mathrm{~mm} \mathrm{Hg}$ ). Third, only black workers exhibited the protective effect for transportation.

\section{Discussion}

Among the 1202 low-income multi-racial/ethnic working class participants in our cohort - of whom $40 \%$ lived below the US poverty line, $79 \%$ reported exposure to at least one social hazard and $82 \%$ at least one high-exposure occupational hazard - only sexual harassment, the least common social hazard, was associated with elevated SBP among the women workers. By contrast, no statistically significant associations were detectable between the other additional highly prevalent social and occupational hazards and SBP; we did, however, find suggestive evidence of an association between SBP and response to unfair treatment, implying that in a context of high exposure, differential susceptibility to the exposure matters. These results interestingly contrast to our prior findings for this same cohort, in which we found associations between self-reported experiences of racial discrimination and two other health outcomes: psychological distress and cigarette smoking (Krieger et al., 2005). Likely explanations for these contrasting findings include: (a) the differential etiologic periods and pathways involving somatic health, mental health, and health behaviors, and (b) the high prevalence of adverse exposures, limiting the ability to detect significant associations.

\section{Study limitations}

Before accepting our findings at face value, it is important to consider study limitations. The first is that despite our high response rate (72\%), we ended up with a smaller analytic dataset than expected, due to management refusal to permit entry to certain workplaces where the union members worked, thereby reducing statistical power. Even so, we did find the expected strong and significant effects for major known risk factors for elevated blood pressure (e.g., gender, age, BMI, hypertension medication, and alcohol). Problems with high levels of missing data also meant we could not control for childhood socioeconomic position, known to influence adult blood pressure (Adair \& Dahly, 2005; Lawlor \& Smith, 2005), but we nevertheless were able to control for two related earlier life variables: country of birth and educational level (Krieger, Williams, \& Moss, 1997). Our use of multiple imputation for the remaining key variables with lower levels of missing data in turn depends on Missing At Random (MAR) assumptions, i.e., that conditional on observed covariates, nonresponse to a specific question is not associated with the dependent variable (SBP). Although these assumptions cannot be tested in our dataset, our inclusion of multiple established correlates of SBP in our imputation model reduced the possibility of violating the MAR assumptions.

Misclassification of exposure could also have affected the study results. Despite our use of validated instruments, 
data on the social and occupational hazards may have been more subject to misclassification than the data on key major risk factors (i.e., self-reported gender, age, and hypertensive medication, and measured BMI). Research on self-report vs. observed occupational hazards at work, for example, has found that workers can both over- and underestimate their exposures (Ikin, Fritschi, \& Sim, 2002; Spielholz, Silverstein, Morgan, Checkoway, \& Kaufman, 2001). Other research indicates that racial discrimination and sexual harassment are more likely to be under- than over-reported, likely due to well-documented psychological tendencies to present oneself positively and to distance oneself cognitively from negative attributes (Hearn \& Parkin, 2005; Hodson \& Esses, 2002; Krieger, 1999). These types of misclassification would likely attenuate estimation of the association, if any existed, between the study exposures and the study outcome. Nevertheless, the prior associations we detected in this cohort between selfreported experiences of racial discrimination and both psychological distress and cigarette smoking imply that differences in etiologic pathways, and not simply sample size and misclassification, might be at issue.

Interpretation: implications of the "inverse trouble law" for studying health inequities

Sustained higher blood pressure does not occur instantaneously; it instead reflects the accumulation of exposures over time, from in utero onwards, which operate via anthropometric as well as psychosocial pathways (Adair \& Dahly, 2005; Lawlor \& Smith, 2005; Pickering, 2001). The cross-sectional association of SBP with concurrent social hazards is thus likely to differ from that of outcomes whose etiologic pathways are chiefly psychosocial and for which the etiologic period can be quite short, e.g., psychological distress and health behaviors.

Also germane are problems posed by the high and relatively limited range of exposure to both poverty and the social and occupational hazards, as well as the correlations between these hazards. As famously argued by Rose (1985), if everyone smokes, smoking would be unrelated to disease, even though it would be responsible for the rates of smoking-related disease; only factors affecting susceptibility to smoking would be detected. It is likely for this reason that we found no association between poverty and SBP - not because poverty is irrelevant, but rather because of the narrow income range among our cohort of lowincome workers (Krieger, 2007). Further underscoring this point, whereas associations between job strain and hypertension have been found in studies examining workers across a wide range of occupations and income levels (Kasl, 1996; Pickering, 2001), job strain was unrelated to hypertension in a study of urban bus drivers, all of whom worked under high-stress conditions and had fairly similar incomes (Albright, Winkleby, Ragland, Fisher, \& Syme, 1992). Research on racial discrimination and blood pressure among African Americans has likewise shown evidence of associations when exposure and socioeconomic position vary sufficiently (Krieger \& Sidney, 1996; Paradies, 2006). By contrast, within a population with uniformly high levels of self-reported exposure to racial discrimination, blood pressure was unrelated to racial discrimination but was associated with response to unfair treatment (Davis, Liu, Quarells, \& Din-Dzietham, 2005). These results, like those of our study, imply the exposure mattered, because if exposure was irrelevant, susceptibility would be too.

Consequently, our finding of an association between sexual harassment and SBP may have been because sexual harassment was the only hazard whose overall prevalence was below 25\%, with the effect strongest among the white women (who were a group less likely to be exposed also to racial discrimination). To our knowledge, this association has not previously been reported, despite the plausibility of sexual harassment (Richman et al., 1999) triggering the same kinds of physiological reactions to stress hypothesized to link experiences of racial discrimination to adverse cardiovascular outcomes (Krieger, 1999; Wyatt et al., 2003). Future research should test if our results can be replicated.

One final noteworthy finding was our observation of much smaller racial/ethnic disparity in blood pressure and hypertension than is typically reported. For example, a recent study based on the 2003-2004 US National Health and Nutrition Examination Study found that in analyses controlling for age, gender, education, and BMI, the odds for being hypertensive were 1.6 times higher among nonHispanic blacks (95\% CI 1.3, 2.0) and 0.7 times lower among Mexican Americans (95\% CI 0.4, 1.1), compared to nonHispanic whites (Ong, Cheung, Man, Lau, \& Lam, 2007). Yet, in our study, we observed no racial/ethnic (or nativity) differences in blood pressure or hypertension when controlling for these same covariates, even as adjustment for these covariates, as expected, did reduce the observed racial/ethnic disparities. Potential explanations might include racial/ethnic patterns of job segregation, whereby the occupations represented in our study were what might be considered relatively good jobs for the black and Latino workers, but less good jobs, comparatively, for the white workers (Baillargeon, 2001; Baron \& Dorsey, 2006). Combined with the "healthy worker" effect, the net result would be to reduce the likelihood of racial/ethnic disparities in blood pressure within the United for Health cohort. Even so, the much stronger association we detected between blood pressure and hypertensive medication among the black and Latino compared to white population attests to racial/ethnic disparities in blood pressure control, as also observed in the general population (Ong et al., 2007).

In summary, the "inverse hazard law" means trouble: for the people affected and for research on what causes their ills. As our data indicate, the highest correlations between the occupational and social hazards occurred among those sociodemographic groups with the least societal power and resources to contest them, an inverse relationship as perverse as the one that inspired Tudor Hart to delineate the "inverse care law". A crucial - and underappreciated - corollary of the "inverse hazard law" is that detecting the health consequences of exposures disproportionately concentrated or uniquely occurring among populations most burdened by economic and social injustice and poor health is unlikely to be achieved by investigations that focus solely on these populations (Krieger, 
2007). To understand health inequities, research instead is needed that contrasts exposures and health status population-wide, not just among those most inequitably exposed. That said, to do this research right, we need clear understanding of the exposures at issue. Studies like United for Health play a useful role in exposing the poorly documented independent and joint distributions of social and occupational hazards and poor health among understudied low-income working class populations - and hence what needs to be addressed to eliminate health inequities.

\section{Appendix. Supplementary data}

Supplementary data associated with this article can be found in the online version at doi:10.1016/j.socscimed. 2008.09.039.

\section{References}

Adair, L., \& Dahly, D. (2005). Developmental determinants of blood pressure in adults. Annual Review of Nutrition, 25, 407-434.

Albright, C. L., Winkleby, M. A., Ragland, D. R., Fisher, J., \& Syme, S. L. (1992). Job strain and prevalence of hypertension in a biracial population of urban bus drivers. American Journal of Public Health, 82, 984-989.

American National Standards Institute, ANSI. (1991). Draft American national standard: Evaluating the effectiveness of hearing conservation programs - Acoustical. New York: American National Standards Institute. ANSI S12.13-1991.

Baillargeon, J. (2001). Characteristics of the healthy worker effect. Occupational Medicine, 16, 359-366.

Barbeau, E. M., Hartman, C., Quinn, M. M., Stoddard, A. M., \& Krieger, N. (2007). Methods for recruiting white, black, and Hispanic working class women and men to a study of physical and social hazards at work: the United for Health Study. International Journal of Health Services, 37, 127-144.

Baron, S. L., \& Dorsey, J. W. (2006). Disparities in occupational and environmental exposures and health. In B. S. Levy, D. H. Wegman, S. L Baron, \& R. K. Sokas (Eds.), Occupational and environmental health: Recognizing and preventing disease and injury. Philadelphia, PA: Lippincott Williams \& Wilkins. R2 Library. http://www.R2library.com/ marc frame.aspx?ResourceID=217. Accessed 10.09.07.

Chobanian, A. V., Bakris, G. L., Black, H. R., Cushman, W. C., Green, L. A. Izzo, J. L., Jr., et al., National High Blood Pressure Education Program Coordinating Committee. (2003). The seventh report of the joint national committee on prevention, detection, evaluation, and treatment of high blood pressure: the JNC 7 report. Journal of the American Medical Association, 289, 2560-2571.

Davis, S. K., Liu, Y., Quarells, R. C., \& Din-Dzietham, R. (2005). Stressrelated racial discrimination and hypertension likelihood in a population-based sample of African Americans: the Metro Atlanta Heart Disease Study. Ethnicity and Disease, 15, 585-593.

European Community Respiratory Health Survey (ECHRS). (1993). Main questionnaire. London, UK: Department of Public Health Medicine UMDS St Thomas Campus.

Ferris, B. G. (1978). Epidemiology standardization project [American Thoracic Society]. American Review of Respiratory Disease, 118(6 Pt 2), $1-120$.

Fitzgerald, L. F., Gelfand, M. J., \& Drasgow, F. (1995). Measuring sexual harassment: theoretical and psychometric advances. Basic Applied Social Psychology, 17, 425-445.

Hart, J. T. (1971). The inverse care law. Lancet, 1(7696), 405-412.

Hays, R. D., \& RAND Corporation. (1989). A five-item measure of socially desirable response set. Educational Psychology Measurement, 49, 629-636.

Hearn, J., \& Parkin, W. (2005). Recognition processes in sexual harassment, bullying, and violence at work: the move to organization violations. In J. E. Gruber, \& P. Morgan (Eds.), In the company of men: Male dominance and sexual harassment (pp. 92-116). Boston: Northeastern University Press.

Hodson, G., \& Esses, V. M. (2002). Distancing oneself from negative attributes and the personal/group discrimination discrepancy. Journal of Experimental Social Psychology, 38, 500-507.
Huang, Y. C., \& Ghio, A. J. (2006). Vascular effects of ambient pollutant particles and metals. Current Vascular Pharmacology, 4, 199-203.

Ikin, J. F., Fritschi, L., \& Sim, M. R. (2002). Reproducibility of survey results from a study of occupation-related respiratory health in the aluminum industry. Applied Occupational and Environmental Hygiene, 17, 774-782.

Karasek, R. (1985). Job content questionnaire and user's guide. Lowell: University of Massachusetts.

Kasl, S. V. (1996). The influence of the work environment on cardiovascular health: a historical, conceptual, and methodological perspective. Journal of Occupational Health Psychology, 1, 42-56.

King, G., Honaker, J., Joseph, A., \& Scheve, K. (2001). Analyzing incomplete political science data: an alternative algorithm for multiple imputation. American Political Science Review, 95, 49-69.

Krieger, N. (1990). Racial and gender discrimination: risk factors for high blood pressure? Social Science \& Medicine, 30, 1273-1281.

Krieger, N. (1994). Epidemiology and the web of causation: has anyone seen the spider? Social Science E' Medicine, 39, 887-903.

Krieger, N. (1999). Embodying inequality: a review of concepts, measures, and methods for studying health consequences of discrimination. International Journal of Health Services, 29, 295-352, [Republished and updated as: Krieger, N. (2000). Discrimination and health. In L. Berkman, \& I. Kawachi (Eds), Social epidemiology (pp. 36-75). Oxford: Oxford University Press.].

Krieger, N. (Ed.). (2004). Embodying inequality: Epidemiologic perspectives. Amityville, NY: Baywood Publishing Co.

Krieger, N. (2007). Why epidemiologists cannot afford to ignore poverty: a commentary for the "Global Theme Issue on Poverty and Human Development. Epidemiology, 18, 658-663.

Krieger, N., \& Sidney, S. (1996). Racial discrimination and blood pressure: the CARDIA study of young black and white adults. American Journal of Public Health, 86, 1370-1378.

Krieger, N., Smith, K., Naishadham, D., Hartman, C., \& Barbeau, E. M. (2005). Experiences of discrimination: validity and reliability of a selfreport measure for population health research on racism and health. Social Science \& Medicine, 61, 1576-1596.

Krieger, N., Waterman, P. D., Hartman, C., Bates, L. M., Stoddard, A. M., Quinn, M. M., et al. (2006). Social hazards on the job: workplace abuse, sexual harassment, and racial discrimination - a study of black, Latino, and white low-income women and men workers (US). International Journal of Health Services, 36, 51-85.

Krieger, N., Williams, D., \& Moss, N. (1997). Measuring social class in US public health research: concepts, methodologies and guidelines. Annual Review of Public Health, 18, 341-378.

Lawlor, D. A., \& Smith, G. D. (2005). Early life determinants of adult blood pressure. Current Opinions in Nephrology and Hypertension, 14 259-264.

Levy, B. S., \& Sidel, V. W. (Eds.). (2006). Social injustice and public health. New York: Oxford University Press.

Lipscomb, H. J., Loomis, D., McDonald, M. A., Argue, R. A., \& Wing, S. (2006). A conceptual model of work and health disparities in the United States. International Journal of Health Services, 36, 25-50.

Lundberg, U. (2002). Psychophysiology of work: stress, gender, endocrine response, and work-related upper extremity disorders. American Journal of Industrial Medicine, 41, 383-392.

National Center for Health Statistics. National Health Interview Survey (NHIS): Questionnaires, datasets, and related documentation, 19972007. http://www.cdc.gov/nchs/about/major/nhis/quest_data_related 1997_forward.htm. Accessed 03.09.07.

Office of Applied Studies, Substance Abuse and Mental Health Services Administration, US Department of Health and Human Services. (2001) Development of computer-assisted interviewing procedures for the national household survey on drug abuse. http://www.oas.samhsa.gov/ nhsda/CompAssistInterview/toc.htm\#TopOfPage. Accessed 10.09.07.

Ong, K. L., Cheung, B. M. Y., Man, Y. B., Lau, C. P., \& Lam, K. S. L. (2007) Prevalence, awareness, treatment, and control of hypertension among United States adults 1999-2004. Hypertension, 49, 69-75.

Paradies, Y. (2006). A systematic review of empirical research on selfreported racism and health. International Journal of Epidemiology, 35, 888-901.

Pickering, T. G. (2001). Mental stress as a causal factor in the development of hypertension and cardiovascular disease. Current Hypertension Reports, 3, 249-254.

Quinn, M. M. (2003). Occupational health, public health, worker health American Journal of Public Health, 93, 526.

Quinn, M. M., Sembajwe, G., Stoddard, A. M., Kriebel, D., Krieger, N., Sorensen, G., et al. (2007). Social disparities in the burden of occupational exposures: results of a cross-sectional study. American Journal of Industrial Medicine, 50, 861-875. 
Richman, J. A., Rospenda, K. M., Nawyn, S. J., Flaherty, J. A., Fendrich, M., Drum, M. L., et al. (1999). Sexual harassment and generalized workplace abuse among university employees: prevalence and mental health correlates. American Journal of Public Health, 89, 358-363.

Rose, G. (1985). Sick individuals and sick populations. International Journal of Epidemiology, 14, 32-38.

SAS Institute. (2001). SAS language reference, version 8. Cary, NC: SAS Institute.

Spielholz, P., Silverstein, B., Morgan, M., Checkoway, H., \& Kaufman, J. (2001). Comparison of self-report, video observation and direct measurement methods for upper extremity musculoskeletal disorder physical risk factors. Ergonomics, 44, 588-613.

Talbott, E. O., Gibson, L. B., Burks, A., Engberg, R., \& McHugh, K. P. (1999). Evidence for a dose-response relationship between occupational noise and blood pressure. Archives of Environmental Health, 54, 71-78.
US Census Bureau. (2004). Poverty thresholds, 2003. http://www.census. gov/hhes/www/poverty/threshld/thresh03.html. Accessed 10.09.07.

Washington State. (2000). Ergonomic rule (WAC 296-62-05174). Appendix $B$ of the Washington State Department of Labor and Industries (LEI). Olympia, WA: Washington Department of Labor and Industries.

Whincup, P. H., Bruce, N. G., Cook, D. G., \& Shaper, A. G. (1992). The Dinamap 1846SX automated blood pressure recorder: comparison with the Hawksley random zero sphygmomanometer under field conditions. Journal of Epidemiology and Community Health, 46, 164-169.

World Health Organization, WHO. (2001). Occupational and community noise. Geneva, Switzerland: WHO.

Wyatt, S. B., Williams, D. R., Calvin, R., Henderson, F. C., Walker, E. R., \& Winters, K. (2003). Racism and cardiovascular disease in African Americans. The American Journal of Medical Science, 325, 315-331. 